Biological and Clinical Sciences Research Journal

ISSN: 2708-2261

www.bcsrj.com

DOI: https://doi.org/10.54112/bcsri.v2020i1.34

Biol. Clin. Sci. Res. J., Volume, 2020: 34

Case study

\title{
UNUSUAL LEUKEMOID REACTION IN A COVID-19 PATIENT: A CASE REPORT
}

\author{
TABASSUM SA ${ }^{1}$, BIBI $^{1}{ }^{1}$, TARIQ $F^{1}$, TARIQ $S^{1}$, RAZA $^{1}$, HAFEEZ MM ${ }^{1,2}$, RANA MA $^{1 *}$ \\ ${ }^{1}$ Department of Internal and Critical Care Medicine, Bahria International Hospital, Lahore, Pakistan \\ ${ }^{2}$ Institute of Molecular Biology and Biotechnology, The University of Lahore, Lahore, Pakistan \\ Corresponding author email: drasimrana@yahoo.com
}

(Received, $12^{\text {th }}$ September 2020, Revised $22^{\text {th }}$ October 2020, Published $23^{\text {th }}$ October 2020)

\begin{abstract}
A leukemoid reaction is a hematological disorder in which the White Blood Cells (WBCs) count may rise more than 50,000 per micro liter ( $\mu \mathrm{L}$ ) accompanied by an increase in Neutrophil precursors. The incidence of this reaction is uncertain. This looks like blood cancer but it is caused by reasons outside bone marrow like severe infections, drug reactions, intoxication, ischemia, inflammation and stress. The WBCs count falls back to normal once this cause is eradicated so we present an unusual case of leukemoid reaction with very high WBCs in a COVID19 patient to create awareness among physicians dealing with such cases.
\end{abstract}

Keywords: COVID 19, Corona virus, viral pneumonia, Leukemoid reaction, Myelodysplastic syndrome

\section{Case report results}

A 76 year old, male patient with past medical history of hypertension (HTN) and ischemic heart disease (IHD) presented in ER with complaints of shortness of breath which had started an hour before his arrival, he also had dry cough for 2 days and intermittent fever for 7 days. His respiratory symptoms rapidly worsened necessitating intubation and ventilation on same day. He was escalated to ICU for elevated level of care. Upon investigations it was found that he was positive for novel coronavirus disease COVID-19 and his WBC count was elevated to $76.6 \times 10^{9} / \mathrm{L}$ with predominant neutrophils, normal platelets count and hemoglobin of patient (Figure 1). His WBC count progressively increased and on $5^{\text {th }}$ day of admission the count had reached to $96.6 \times 10^{9} / \mathrm{L}$ (Table 1). His peripheral blood smear revealed a picture consistent with leukemoid reaction with neutrophilic leukocytosis with left shift and presence of myelocytes and metamyelocytes. The JAK 2 mutation was tested which was negative thus ruling out myeloproliferative disorders. His Leukocyte Alkaline Phosphate Score (LAP) score was 380 (Figure 2). It was further revealed from his family member, he had a normal WBC count before contracting the infection. Unfortunately, the patient expired on $5^{\text {th }}$ day of admission because of acute respiratory distress syndrome (ARDS) and refractory respiratory failure and hence further investigations could not be undertaken.

\section{Discussion}

A leukemoid reaction is a hematological disorder, in which leukocyte count may exceed 50,000 cells $/ \mu \mathrm{L}$, precipitated by causes outside the bone marrow
(Hunter Jr, 2007; Nimieri et al., 2003; Padmakumar et al., 2014; Potasman and Grupper, 2013; Sakka et al., 2006). Although it resembles leukemia, it is not cancer and the leukocyte count often comes back to normal when the underlying cause is treated. There is a significant increase in early mature neutrophil precursors circulating in the peripheral blood and a differential count revealing marked left shift. A Leukemoid Reaction can be caused by severe infections, such as colitis due to Clostridium difficile, disseminated tuberculosis, and severe shigellosis (ul Haque and ul Aan, 2010). Few drugs can also precipitate a leukemoid reaction e.g., corticosteroids, minocycline, recombinant hematopoietic growth factors (Ganti et al., 2003). Intoxication secondary to ethylene glycol (Mycyk et al., 2002) can also cause leukemoid reaction rarely. Other rare causes include mesenteric inflammatory pseudo tumor, alcoholic steatohepatitis, and retroperitoneal hemorrhage (Kutluk et al., 2002; Marinella, 1998; Morales et al., 2006; Spahr et al., 2008). The diagnosis of leukemoid reaction is made by: (i) a full blood count with a peripheral blood smear that shows marked mature neutrophilia with a left shift; (ii) a high leukocyte alkaline phosphatase (LAP) score; (iii) increased cellularity of bone marrow with orderly maturation and morphology of all the elements; (iv) no karyotypic abnormalities on cytogenetic analysis; (v) Immunophenotyping of peripheral blood and bone marrow; (vi) a high serum level of hemopoietic growth factors, in the case of a cytokine-producing tumor; and (vii) a polyclonal pattern of blood neutrophils in clonality studies (Fauci, 2020; Sakka et al., 2006; Schniewind et al., 2005).

Differential Diagnoses:

[Citation: Tabassum, SA., Bibi, T., Tariq, F., Tariq, S., Raza, S., Hafeez, M.M., Rana, M.A. (2020). Unusal leukemoid reaction in a COVID-19 patient: A case report. Biol. Clin. Sci. Res. J., 2020: 34. doi: https://doi.org/10.54112/bcsrj.v2020i1.34] 
1. Chronic Myeloid Leukemia

2. Chronic Neutrophilic Leukemia

The novel corona virus disease 2019 (COVID-19) caused by a pathogen named severe acute respiratory syndrome coronavirus 2 (SARS-CoV-2), emerged in Wuhan city of China in December 2019 (Fauci, 2020). Coronavirus disease was declared a pandemic and it has created a public health emergency in Pakistan and many other countries. With number of cases still being reported, its spread is expected to continue. Before this pandemic, very little was known about SARS-CoV-2 virus and its pathogenicity among humans. Our knowledge of this

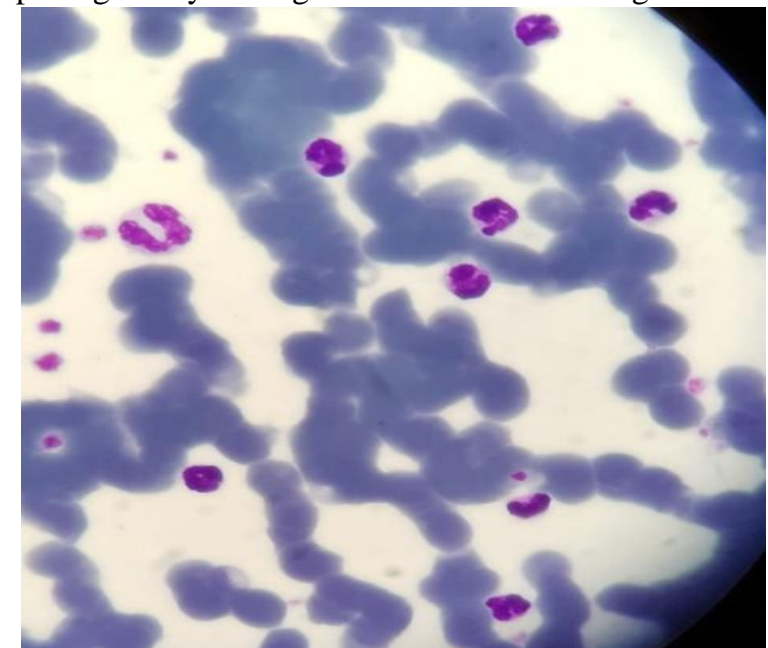

Figure 1: Peripheral blood smear

Table 1.The sequential complete blood count

\begin{tabular}{|c|c|c|c|c|c|c|c|}
\hline $\begin{array}{c}\text { Date and } \\
\text { time }\end{array}$ & $\begin{array}{l}\text { WBCs } \\
\text { count }\end{array}$ & Neutrophils & Lymphocytes & Monocytes & Eosinophils & Platelets & Hemoglobin \\
\hline $\begin{array}{c}\text { 24/07/2020 } \\
\text { 8:16PM }\end{array}$ & $\begin{array}{l}76.6 \mathrm{X} \\
10^{9} / \mathrm{L}\end{array}$ & $72 \%$ & $07 \%$ & $20 \%$ & $01 \%$ & $156 \times 10^{9} / \mathrm{L}$ & $11.3 \mathrm{gm} \%$ \\
\hline $\begin{array}{c}\text { 25/07/2020 } \\
\text { 8:52PM }\end{array}$ & $\begin{array}{l}72.5 \mathrm{X} \\
10^{9} / \mathrm{L}\end{array}$ & $78 \%$ & $06 \%$ & $15 \%$ & $01 \%$ & $133 \times 10^{9} / \mathrm{L}$ & $11.0 \mathrm{gm} \%$ \\
\hline $\begin{array}{c}\text { 26/07/2020 } \\
\text { 4:57AM }\end{array}$ & $\begin{array}{c}69.5 \mathrm{X} \\
10^{9} / \mathrm{L}\end{array}$ & $80 \%$ & $06 \%$ & $12 \%$ & $02 \%$ & $98 \times 10^{9} / \mathrm{L}$ & $10.6 \mathrm{gm} \%$ \\
\hline $\begin{array}{c}27 / 07 / 2020 \\
6: 28 \mathrm{AM}\end{array}$ & $\begin{array}{l}79.6 \mathrm{X} \\
10^{9} / \mathrm{L}\end{array}$ & $83 \%$ & $06 \%$ & $10 \%$ & $01 \%$ & $91 \times 10^{9} / \mathrm{L}$ & $10.7 \mathrm{gm} \%$ \\
\hline $\begin{array}{c}\text { 27/07/2020 } \\
2: 10 P M\end{array}$ & $\begin{array}{c}96.6 \mathrm{X} \\
10^{9} / \mathrm{L}\end{array}$ & $83 \%$ & $09 \%$ & $07 \%$ & $01 \%$ & $78 \times 10^{9} / \mathrm{L}$ & $10.1 \mathrm{gm} \%$ \\
\hline
\end{tabular}

\section{Conflict of interest}

The authors showed absence of conflict of interest for manuscript publication.

\section{References}

Fauci, A. S. (2020). Covid-19-Navigating the uncharted, editorial published on February 28, 2020, at. NEJM. org.

Ganti, A. K., Potti, A., and Mehdi, S. (2003). Case 2. Metastatic non-small-cell lung cancer novel corona virus is limited and progressively evolving. The spectrum of disease, clinical manifestations, and pathophysiology associated with this disease will be further explained with the ongoing research on the virus. Our aim with this clinical case report is to present the unusual finding of Leukemoid reaction in this patient with COVID-19 positive PCR. With unfortunate death of our patient, we could not ascertain if the leukemoid reaction was secondary to the infection caused by COVID-19, as further investigations to differentiate it from myelodysplastic syndromes could not be carried out.

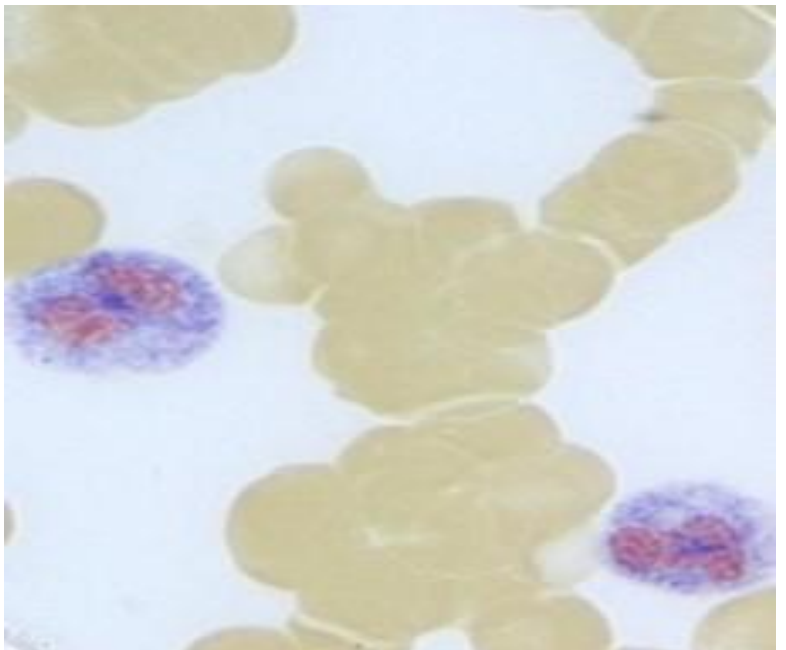

Figure 2: LAP score

presenting with leukocytosis. Journal of clinical oncology 21, 168-170.

Hunter Jr, K. W. (2007). Murine mammary carcinoma 4T1 induces a leukemoid reaction with splenomegaly: association with tumorderived growth factors. Experimental and molecular pathology 82, 12-24.

Kutluk, T., Emir, S., Karnak, I., Çaglar, M., and Büyükpamukçu, M. (2002). Mesenteric inflammatory pseudotumor: unusual presentation with leukemoid reaction and

[Citation: Tabassum, SA., Bibi, T., Tariq, F., Tariq, S., Raza, S., Hafeez, M.M., Rana, M.A. (2020). Unusal leukemoid reaction in a COVID-19 patient: A case report. Biol. Clin. Sci. Res. J., 2020: 34. doi: https://doi.org/10.54112/bcsrj.v2020i1.34] 
massive calcified mass. Journal of pediatric hematology/oncology 24, 158-159.

Marinella, M. A. (1998). Extreme leukemoid reaction associated with retroperitoneal hemorrhage. Archives of internal medicine 158, 300-301.

Morales, A. M., Hashimoto, L. A., and Mokhtee, D. (2006). Alcoholic hepatitis with leukemoid reaction after surgery. Journal of gastrointestinal surgery 10, 83-85.

Mycyk, M. B., Drendel, A., Sigg, T., and Leikin, J. B. (2002). Leukemoid response in ethylene glycol intoxication. Veterinary and human toxicology 44, 304-306.

Nimieri, H., Makoni, S., Madziwa, F., and Nemiary, D. (2003). Leukemoid reaction response to chemotherapy and radiotherapy in a patient with cervical carcinoma. Annals of hematology 82, 316-317.

Padmakumar, G., Ravikrishnan, J., Jayakumar, P., and Prasad, K. (2014). Leukemoid like reaction in a post $\mathrm{CABG}$ patient. Indian Journal of Anaesthesia 58, 315.

Potasman, I., and Grupper, M. (2013). Leukemoid reaction: spectrum and prognosis of 173 adult patients. Clinical Infectious Diseases 57, e177e181.

Sakka, V., Tsiodras, S., Giamarellos-Bourboulis, E. J., and Giamarellou, H. (2006). An update on the etiology and diagnostic evaluation of a leukemoid reaction. European Journal of Internal Medicine 17, 394-398.

Schniewind, B., Christgen, M., Hauschild, A., Kurdow, R., Kalthoff, H., and Jürgen Klomp, H. (2005). Paraneoplastic leukemoid reaction and rapid progression in a patient with malignant melanoma: establishment of KT293, a novel G-CSF-secreting melanoma cell line. Cancer biology \& therapy 4, 30-34.

Spahr, L., Lambert, J. F., Rubbia-Brandt, L., Chalandon, Y., Frossard, J. L., Giostra, E., and Hadengue, A. (2008). Granulocyte-colony stimulating factor induces proliferation of hepatic progenitors in alcoholic steatohepatitis: A randomized trial. Hepatology 48, 221-229.

ul Haque, A., and ul Aan, N. (2010). Leukemoid reaction: unusual causes. International Journal of Pathology 8, 39-40. and reproduction in any medium or format, as long as you give appropriate credit to the original author(s) and the source, provide a link to the Creative Commons licence, and indicate if changes were made. The images or other third party material in this article are included in the article's Creative Commons licence, unless indicated otherwise in a credit line to the material. If material is not included in the article's Creative Commons licence and your intended use is not permitted by statutory regulation or exceeds the permitted use, you will need to obtain permission directly from the copyright holder. To view a copy of this licence, visit http://creativecommons.org/licen ses/by/4.0/.

(C) The Author(s) 2020

\section{(c) (7) \&}

Open Access This article is licensed under a Creative Commons Attribution 4.0 International License, which permits use, sharing, adaptation, distribution

[Citation: Tabassum, SA., Bibi, T., Tariq, F., Tariq, S., Raza, S., Hafeez, M.M., Rana, M.A. (2020). Unusal leukemoid reaction in a COVID-19 patient: A case report. Biol. Clin. Sci. Res. J., 2020: 34. doi: https://doi.org/10.54112/bcsrj.v2020i1.34] 